\title{
Canadian guidelines for postoperative surveillance of upper urinary tract urothelial carcinoma
}

\author{
Anil Kapoor, MD, FRCSC,; Christopher B. Allard, MD; ${ }^{*}$ Peter Black, MD, FRCSC, ${ }^{+}$Wassim Kassouf, MD, FRCSC,; \\ Christopher Morash, MD, FRCSC,; Ricardo Rendon, MD, FRCSC ${ }^{ \pm}$
}

*Division of Urology, McMaster University, Hamilton, ON; †Department of Urologic Science, University of British Columbia, Vancouver, BC; §Department of Surgery (Urology), McGill University, Montreal, QC; * Department of Surgery, Division of Urology, University of Ottawa, Ottawa, ON; \pm Department of Urology, Dalhousie University, Halifax, NS

Cite as: Can Urol Assoc J 2013;7(9-10):306-11. http://dx.doi.org/10.5489/cuaj.1578 Published online October 7, 2013.

\section{Introduction}

Upper urinary tract urothelial carcinoma (UTUC) is a rare malignancy, accounting for $5 \%$ of urothelial tumours. ${ }^{1}$ The gold standard management for non-metastatic UTUC is radical nephrouretectomy with bladder cuff excision. ${ }^{2}$ Nephronsparing procedures, including segmental ureterectomy and endoscopic ablation or resection, are often employed in select patients. ${ }^{3}$ Postoperative recurrences are common. The primary aims of postoperative surveillance for UTUC are to identify urothelial recurrences, de novo tumours of the urinary tract, and distant metastases at early stages when they may be amenable to treatment. The rarity of the disease, as well as the heterogeneity of treatments, complicates the task of developing a standard follow-up protocol.

Multiple studies report on postoperative recurrence and prognosis for UTUC. By performing a systematic literature review, we generated an evidence-based consensus protocol for the surveillance of patients after surgery for UTUC based on the predictors, timing and locations of recurrences reported in the literature. The decision to provide neoadjuvant or adjuvant treatments is beyond the scope of this guideline and will not be reviewed. Wherever possible, the levels of evidence and grades of recommendation are noted using the modified Oxford Centre for Evidence-based Medicine system.

\section{Methods}

A systematic literature review of the electronic databases Embase, Medline and Cochrane was performed using the following search terms, their synonyms, related terms and relevant exploded terms: upper tract, urothelial carcinoma, transitional cell carcinoma, nephrouretectomy, ureterectomy, endoscopy, ureteroscopy, nephroscopy, percutaneous, follow-up, surveillance, recurrence, outcomes and prognosis. No language restrictions were implemented. Citations from included articles and review articles were manually searched.

The inclusion and exclusion criteria were defined a priori. We included studies which reported rates and/or patterns of recurrence after surgery (nephroureterectomy or nephronsparing procedures) for UTUC. Nephron-sparing procedures include segmental ureterectomy and endoscopic (retrograde or antegrade) ablation or resection. Non-observational studies were excluded. No sample size limitations were applied to prospective studies. For retrospective studies, minimum sample sizes for nephroureterectomy series and nephronsparing series were 100 and 20 respectively, with exceptions for special reasons by author consensus and with explanation. When multiple studies reporting on the same patient population were identified, we attempted to include only the most relevant study. Studies with major design flaws were excluded by author consensus and with explanation. For recurrence/metastases rates, weighted means across all relevant studies were calculated when possible; these are reported as "mean (range of means)." Where applicable, the weighted mean of follow-up duration is also included within parentheses.

\section{Results}

In total, 59 studies satisfied the inclusion criteria, of which 33 pertained to nephroureterectomy ${ }^{4-36}$ and 26 to nephronsparing procedures (Fig. 1). ${ }^{37-62}$ One prospective study was included; ${ }^{26}$ the rest are retrospective case-series, including several large multicentre series. One retrospective study of patients after nephroureterectomy with a sample size $<100$ was included by author consensus because of its large sample of pT3 tumours. ${ }^{27}$ No studies were excluded for major 


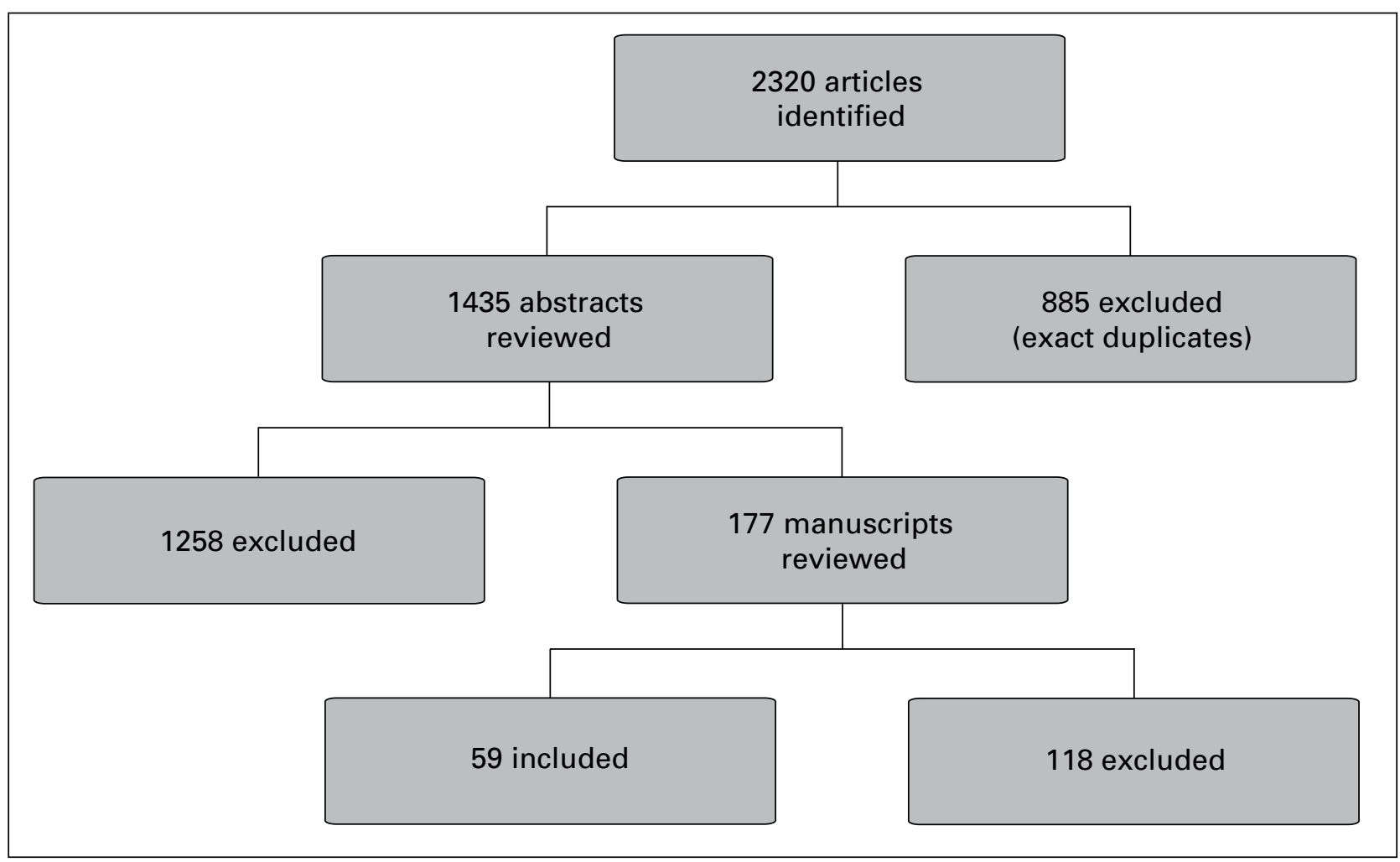

Fig. 1. Results of systematic literature search.

design flaws. In virtually all series, formal lymphadenectomy was not performed and methods of bladder cuff excision were not standardized. All studies report relatively high rates of postoperative recurrence.

\section{Prognostic variables}

Many studies report variables which are predictive of postnephroureterectomy recurrence on multivariate analyses. The most commonly cited variable is tumour stage. In a retrospective series of 301 patients who underwent nephroureterectomy, $\mathrm{Li}$ and colleagues reported 5 -year recurrence-free survival for patients with $\mathrm{pTa} / \mathrm{pTis} / \mathrm{pT} 1, \mathrm{pT} 2$, pT3, and pT4 tumours of $76.6 \%, 65.4 \%, 41.2 \%$, and $0 \%$, respectively. ${ }^{16}$ In a large retrospective multicentre series of 1363 patients, Margulis and colleagues reported 5-year extravesical recurrence-free survival for $\mathrm{pTa} / \mathrm{pTis}$, pT1, $\mathrm{pT}$, pT3, and pT4 tumours of $91.8 \%, 88 \%, 71 \%, 48 \%$, and $4.7 \%$, respectively. ${ }^{19}$ Additionally, tumour grade is associated with oncologic outcomes. While there is correlation between stage and grade, ${ }^{44,63}$ each independently predicts postoperative recurrence. ${ }^{19}$

Although lymphadenectomy is seldom performed for clinically node-negative disease, ${ }^{64}$ pathologic lymph node status is a strong predictor of post-nephroureterectomy recurrence. ${ }^{19,21}$ Among 1363 patients, those with pathologically positive lymph nodes $(\mathrm{N}+)$ had 5 -year recurrence-free sur- vival of $29 \%$ compared to $73 \%$ in patients with negative (N0) or unknown (Nx) lymph node status. ${ }^{19}$ In a large retrospective multicentre Canadian series, 5-year overall survival rates for $\mathrm{Nx}, \mathrm{N} 0$, and $\mathrm{N}+$ patients were $66.1 \%, 66.0 \%$ and $29.8 \%$, respectively. ${ }^{31}$

Other prognostic variables following nephroureterectomy include lymphovascular invasion, concomitant carcinoma in situ (CIS), positive surgical margins, ureteral tumour location (as opposed to renal pelvis), previous or concomitant bladder tumours, tumour multifocality, and lack of postoperative intravesical mitomycin C instillation. ${ }^{4,6,7,10-12,14-19,21-24,26,28-36,65-69}$ The rates of recurrence stratified by these variables are seldom reported.

Owing to the small sample sizes of most studies, multivariate analyses examining the predictors of recurrence after nephron-sparing procedures are lacking. Tumour grade is associated with recurrence; in a retrospective series of 40 patients, $75 \%$ of patients with high-grade disease had recurrence by 2 months and ultimately underwent nephroureterectomy. ${ }^{43}$ Similarly, among 60 patients with a mean followup of 51 months, disease-specific survival for patients with grades 1, 2, and 3 tumours was $100 \%, 94 \%$, and $62 \%$, respectively. ${ }^{54}$ Additionally, tumour stage and multifocality correlate with recurrence after nephron-sparing procedures. ${ }^{44,47,52,56}$ Due to a lack of adequately powered studies, additional prognostic factors following nephron-sparing procedures are presently unknown. 


\section{Bladder recurrences}

Among all patients with available data, bladder recurrences occurred following nephroureterectomy in $29.0 \%$ (22\%-47\%; 35.9 months). In a retrospective series of 422 patients, Kim and colleagues reported median times to bladder recurrence and muscle-invasive bladder cancer of 8 and 17 months, respectively. ${ }^{34}$ The median reported time to bladder recurrence across all studies was 6 to 12 months. Bladder recurrences were noted as early as 1 month postnephroureterectomy.

Following nephron-sparing procedures, bladder recurrences occurred in about $34 \%$ of patients. ${ }^{70}$ In a retrospective series of 30 patients, the mean time to recurrence was 7 months and ranged from 6 to 72 months. ${ }^{52}$

\section{Extravesical recurrences}

Across all studies, post-nephroureterectomy recurrences of the retroperitoneum or pelvis occurred in a mean $4.6 \%$ $(0-12 \% ; 32.7$ months). UTUC of the contralateral upper tract occurred in a mean $2.2 \%(0-4.6 \% ; 46.7$ months). Several studies report very low incidences of port-site recurrences, usually associated with inadvertent entry into the collecting system. ${ }^{10,18,20,23,25}$ Among 72 patients with pT3 tumours and a median follow-up of 26.5 months, recurrences of the retroperitoneum/pelvis and contralateral upper tract were observed in $7 \%$ and $3 \%$, respectively. ${ }^{27}$

Distant metastases occurred following nephroureterectomy in $16.4 \%$ of patients $(8 \%-28 \% ; 46.8$ months). The reported sites of metastases included retroperitoneal lymph nodes in $5.2 \%(0-9.8 \%$; 49.0 months), lung in $4.8 \%(0-8 \%$; 50.2 months), bone in $4.1 \%$ (0-9\%; 50.2 months) and liver in $3.7 \%$ (0-5\%; 50.2 months). Less common sites included brain, adrenal gland and non-regional lymph nodes. The median time to metastases was 13 to 16 months. Metastases were reported as early as 1 month and as late as 50 months postoperatively.

Following nephron-sparing procedures, recurrences of the ipsilateral upper tract are common. In a retrospective series of 30 patients who underwent ureteroscopic or percutaneous management of UTUC, 90\% developed upper tract recurrences necessitating a mean 3.3 endoscopic procedures per patient and nephroureterectomy in $33 \% .{ }^{52}$ In a systematic review by Cutress and colleagues, upper urinary tract recurrences occurred in $53 \%$ of patients. ${ }^{70}$ Upper tract recurrence rates among patients with low- and high-grade tumours were $48 \%$ and $60 \%$, respectively. Most recurrences were managed endoscopically, while $19 \%$ of patients underwent nephroureterectomy. Distant metastases occurred in $9 \%$ of patients.

\section{Surveillance protocol}

These guidelines for surveillance after surgical management of UTUC are based on a systematic review of primarily non-randomized retrospective series which report on patterns of postoperative recurrence (Level 3). None of these studies evaluated specific surveillance protocols. It remains unproven whether surveillance in asymptomatic individuals is superior to symptom-directed investigation. While direct evidence for a survival benefit is lacking, these recommendations are based on an assumption that early diagnosis of recurrence is optimal, and from extrapolations from level 3 evidence (Grade C).

The intensity of postoperative surveillance of UTUC varies according to the risk of disease recurrence. While multiple factors are independently associated with adverse oncologic outcomes, patterns of recurrence stratified by prognostic variables other than tumour stage, grade and lymph node status are undefined. This surveillance protocol is therefore based on pathologic tumour stage, grade and lymph node status.

The recommended protocol for postoperative surveillance of UTUC is shown in Table 1. Routine blood work should include renal function tests and a metabolic panel, including liver function tests, calcium and alkaline phosphatase. Although other published guidelines have recommended cystoscopy and urine cytology at 3 months then yearly after nephroureterectomy, ${ }^{2}$ we advocate a more aggressive surveillance protocol given the high rates of urothelial recurrences in all patients and the reported median time to bladder recurrence of 6 to 12 months. Thus, the bladder should be assessed with cytology and cystoscopy in all patients at months 3, 6, 12, 18, 24 and annually thereafter up to 10 years of recurrence-free survival (Grade C).

Most patients following nephron-sparing procedures will develop ipsilateral upper tract recurrences. Computed tomography urography (CTU) lacks sensitivity to identify up to $75 \%$ of these recurrences. ${ }^{56}$ Furthermore, the sensitivity of ureteroscopy with selective cytology or biopsy is superior to retrograde pyelography alone. ${ }^{71}$ The ipsilateral upper tract should therefore be assessed by ureteroscopy and selective cytology or biopsy in all patients following nephron-sparing procedures at months 3, 6, 12, 18, 24 and annually thereafter up to 10 years of recurrence-free survival (Grade C).

To assess for local, contralateral and distant metastases in patients after nephroureterectomy or nephron-sparing procedures, imaging of the abdomen and pelvis with CTU is recommended (Grade $\mathrm{C}$ ). Magnetic resonance imaging urography (MRI) or ultrasound (US) may be substituted for CTU in patients with contraindications to CTU (Grade D). Chest $\mathrm{x}$-ray (CXR) is recommended to assess for lung metastases (Grade C). Bone scan is indicated in the presence of bone pain, elevated calcium or elevated alkaline phosphatase to 


\begin{tabular}{|c|c|c|c|c|c|c|c|c|c|c|}
\hline \multirow[t]{2}{*}{ Pathology } & \multirow[t]{2}{*}{ Investigations } & \multicolumn{9}{|c|}{ No. months after surgery for UTUC } \\
\hline & & 3 & 6 & 12 & 18 & 24 & 30 & 36 & 48 & 60 \\
\hline \multicolumn{11}{|c|}{ LG $p T<2 \mathrm{Nx} / 0$} \\
\hline & $\mathrm{Hx}$ and PE & $x$ & $x$ & $x$ & $x$ & $x$ & & $x$ & $x$ & $x$ \\
\hline & Blood work & $x$ & $x$ & $x$ & $x$ & $x$ & & $x$ & $x$ & $x$ \\
\hline & Urine cytology & $x$ & $x$ & $x$ & $\mathrm{x}$ & $\mathrm{x}$ & & $x$ & $x$ & $x$ \\
\hline & Cystoscopy & $x$ & $x$ & $x$ & $x$ & $x$ & & $x$ & $\mathrm{x}$ & $x$ \\
\hline & CXR & & & $x$ & & $x$ & & $x$ & $\mathrm{x}$ & $x$ \\
\hline & CTU & & & $x$ & & $x$ & & $x$ & $x$ & $x$ \\
\hline & \pm Ureteroscopy* & $x$ & $x$ & $x$ & $x$ & $\mathrm{x}$ & & $x$ & $x$ & $x$ \\
\hline \multicolumn{11}{|c|}{$\begin{array}{l}\text { HG pT<2 Nx/0 or } \\
\text { LG pT2 Nx/0 }\end{array}$} \\
\hline & $\mathrm{Hx}$ and $\mathrm{PE}$ & $x$ & $x$ & $x$ & $x$ & $x$ & & $x$ & $x$ & $x$ \\
\hline & Blood work & $x$ & $x$ & $x$ & $x$ & $x$ & & $x$ & $x$ & $x$ \\
\hline & Urine cytology & $x$ & $x$ & $x$ & $x$ & $x$ & & $x$ & $x$ & $x$ \\
\hline & Cystoscopy & $x$ & $x$ & $x$ & $x$ & $x$ & & $x$ & $x$ & $x$ \\
\hline & CXR & & $x$ & $\mathrm{x}$ & $x$ & $x$ & & $x$ & $x$ & $\mathrm{x}$ \\
\hline & CTU & & $x$ & $x$ & $x$ & $x$ & & $x$ & $x$ & $x$ \\
\hline & \pm Ureteroscopy* & $x$ & $x$ & $\mathrm{x}$ & $x$ & $x$ & & $x$ & $x$ & $\mathrm{x}$ \\
\hline \multicolumn{11}{|c|}{ LG/HG pT>2 or pN+ } \\
\hline & $\mathrm{Hx}$ and $\mathrm{PE}$ & $x$ & $x$ & $x$ & $x$ & $x$ & & $x$ & $x$ & $x$ \\
\hline & Blood work & $x$ & $x$ & $x$ & $x$ & $x$ & & $x$ & $x$ & $x$ \\
\hline & Urine cytology & $x$ & $x$ & $x$ & $x$ & $x$ & & $x$ & $x$ & $x$ \\
\hline & Cystoscopy & $x$ & $x$ & $x$ & $x$ & $x$ & & $x$ & $x$ & $x$ \\
\hline & CXR & $x$ & $x$ & $x$ & $x$ & $x$ & $x$ & $x$ & $x$ & $x$ \\
\hline & CTU & $x$ & $x$ & $x$ & $x$ & $x$ & $x$ & $x$ & $x$ & $x$ \\
\hline & \pm Ureteroscopy* & $x$ & $x$ & $\mathrm{x}$ & $x$ & $\mathrm{x}$ & & $x$ & $\mathrm{x}$ & $x$ \\
\hline
\end{tabular}

assess for bone metastases (grade $\mathrm{C}$ ). In patients with lowgrade, $\mathrm{pT}<2(\mathrm{pTa} / \mathrm{pTis} / \mathrm{pT} 1) \mathrm{pNx} / \mathrm{pN} 0$ disease, imaging of the abdomen and chest is recommended annually (Grade C). Patients with $\mathrm{pT} 2 \mathrm{pNx} / \mathrm{pNO}$ of any grade or high-grade pT $<2$ should undergo imaging every 6 months for 2 years then annually thereafter (Grade C). Patients with pT $>2$ or $\mathrm{pN}+$ of any grade should undergo imaging at 3 months, 6 months, then every 6 months for the first 3 years followed by annually thereafter (Grade $\mathrm{C}$ ).

In the absence of evidence for an optimal duration of surveillance, we recommend lifelong annual surveillance with history, physical examination, blood work, urine cytology and abdominal/chest imaging in all patients with high-grade tumours or $\mathrm{p} \geq 2$ or $\mathrm{pN}+$ (Grade D). Annual cystoscopy and ipsilateral ureteroscopy (following nephron-sparing procedures) may be omitted after 10 years of recurrence-free survival (Grade D). Patients with low-grade $\mathrm{pT}<2 \mathrm{pN} 0 / x$ may be discharged from annual surveillance after 10 years of recurrence-free survival (Grade D). A summary of these guidelines follows.

\section{Surveillance for low grade $\mathrm{pT}<2 \mathrm{pNx} / \mathrm{pNO}$ patients}

History, physical examination, blood work, urine cytology and cystoscopy should be performed at months 3, 6, 12, 18, 24 and annually thereafter (Grade C). CXR and CTU should be performed annually (Grade C). Following nephron-sparing procedures, ipsilateral ureteroscopy with selective cytology or biopsy should be performed at months 3, 6, 12, 18, 24 and annually thereafter (Grade C). Patients may be discharged from surveillance after 10 years of recurrencefree survival (Grade D)

\section{Surveillance for high grade $\mathrm{pT}<2 \mathrm{pNx} / \mathrm{pNO}$ or any grade $\mathrm{pT} 2 \mathrm{pNx} /$ pNO patients}

History, physical examination, blood work, urine cytology and cystoscopy should be performed at months 3, 6, 12, 18, 24 and annually thereafter (Grade C). CXR and CTU should be performed every 6 months for 2 years then annually thereafter (Grade C). Following nephron-sparing procedures, ipsilateral ureteroscopy with selective cytology or biopsy 
should be performed at months 3, 6, 12, 18, 24 and annually thereafter (Grade C). Cystoscopy and ureteroscopy may be omitted from the surveillance protocol after 10 years of recurrence-free survival (Grade D).

\section{Surveillance for any grade $\mathrm{pT}>2$ or $\mathrm{pN}+$ patients}

History, physical examination, blood work, urine cytology, and cystoscopy should be performed at months 3, 6, 12, 18, 24 and annually thereafter (Grade C). CXR and CTU should be performed at months 3, 6, 12, 18, 24, 30, 36 and annually thereafter (Grade C). Following nephron-sparing procedures, ipsilateral ureteroscopy with selective cytology or biopsy should be performed at months 3, 6, 12, 18, 24 and annually thereafter (Grade C). Cystoscopy and ureteroscopy may be omitted from the surveillance protocol after 10 years of recurrence-free survival (Grade D).

Competing interests: Dr. Kapoor is a member of the Speakers bureau for, and has received grants and honoraria from, Pfizer Oncology, GSK Oncology, Novartis Oncology and Amgen. He has also participated in clinical trials within the past 2 years with NCIC, Pfizer, GSK, Novartis and Amgen. Dr. Allard does not have an affiliation with a pharmaceutical, medical device or communications organization. Dr. Black is a member of the ad hoc Advisory Boards for Amgen, Janssen, Ferring and Astellas. He has received an industry-partnered grant (2012) from GenoneDx. Dr. Kassouf is an Advisory Board member and a speaker for Amgen and Astellas. He has also received grants and honoraria from these companies. He is currently participating in unpaid clinical trials within the past 2 years. Dr. Morash does not have an affiliation with a pharmaceutical, medical device or communications organization. Dr. Rendon is a member of the Advisory Board and the Speakers bureau for Amgen, Astellas, Ferring and Janssen.

This paper has been peer-reviewed.

\section{References}

1. Munoz JJ, Ellison LM, Upper tract urothelial neoplasms: incidence and survival during the last 2 decades. J Urol 2000;164:1523-5. http://dx.doi.org/10.1016/S0022-5347(05)67019-X

2. Roupret $M$, Babjuk $E$, Comperat $R$, et al. European guidelines on upper tract urothelial carcinomas: 2013 update. Eur Urol 2013;63:1059-71. http://dx.doi.org/10.1016/i.eururo.2013.03.032

3. Argyropoulos AN, Tolley DA. Upper urinary tract transitional cell carcinoma: current treatment overview of minimally invasive approaches. BJU Int 2007;99:982-7. http://dx.doi.org/10.1111/i.1464410X.2007.06870.x

4. Allard, C, Alamri, A, Dason, $\mathrm{S}$ et al. The method of bladder cuff excision during laparoscopic radical nephroureterectomy does not affect oncologic outcomes in upper tract urothelial carcinoma. World I Urol 2012;31:175-81. http://dx.doi.org/10.1007/s00345-012-0915-0

5. Berger A, Haber GP, Kamoi K, et al. Laparoscopic radical nephroureterectomy for upper tract transitional cell carcinoma: oncological outcomes at 7 years. J Urol 2008;180:849-54. http://dx.doi.org/10.1016/i. juro.2008.05.042

6. Bolenz C, Fernandez MI, Trojan L, et al. Lymphovascular invasion and pathologic tumor stage are significant outcome predictors for patients with upper tract urothelial carcinoma. Urology 2008:72:364-9. http:// dx.doi.org/10.1016/j.urology.2008.04.032

7. El Fettouh HA, Rassweiler JJ, Schulze $M$, et al. Laparoscopic radical nephroureterectomy: results of an international multicenter study. Eur Urol 2002;42:447-52. http://dx.doi.org/10.1016/S03022838(02)00370-6

8. Hsueh TY, Huang YH, Chiu AW, et al. Survival analysis in patients with upper urinary tract transitional cell carcinoma: a comparison between open and hand-assisted laparoscopic nephroureterectomy. BJU Int 2007;99:632-6. http://dx.doi.org/10.1111/i.1464-410X.2006.06665.x
9. Huang WW, Huang HY, Liao AC et al. Primary urothelial carcinoma of the upper tract: important clinicopathological factors predicting bladder recurrence after surgical resection. Pathol Int 2009;59:642-9. http://dx.doi.org/10.1111/i.1440-1827.2009.02420.x

10. Kamihira 0, Hattori R, Yamaguchi A, et al. Laparoscopic radical nephroureterectomy: a multicenter analysis in Japan. Eur Urol 2009;55:1397-409. http://dx.doi.org/10.1016/i.eururo.2009.03.003

11. Kikuchi E, Horiguchi Y, Nakashima J, et al. Lymphovascular invasion independently predicts increased disease specific survival in patients with transitional cell carcinoma of the upper urinary tract. I Urol 2005;174:2120-4. http://dx.doi.org/10.1097/01.ju.0000181801.22474.8b

12. Kim DS, Lee $\mathrm{YH}$, Cho KS, et al. Lymphovascular invasion and $\mathrm{pT}$ stage are prognostic factors in patients treated with radical nephroureterectomy for localized upper urinary tract transitional cell carcinoma. Urology 2009;75:328-32. http://dx.doi.org/10.1016/i.urology.2009.07.1350

13. Koda S, Mita K, Shigeta $M$, et al. Risk factors for intravesical recurrence following urothelial carcinoma of the upper urinary tract: no relationship to the mode of surgery. Jpn I Clin Oncol 2007;37:296-301. http://dx.doi.org/10.1093/iico/hym016

14. Lee SE, Hong SK, Han BK, et al. Prognostic significance of tumor necrosis in primary transitional cell carcinoma of the upper urinary tract. Jpn J Clin Oncol 2007;37:49-55. http://dx.doi.org/10.1093/ iico/hyll23

15. Li CC, Chang TH, Wu WJ, et al. Significant predictive factors for prognosis of primary upper urinary tract cancer after radical nephroureterectomy in Taiwanese patients. Eur Urol 2008;54:1127-37. http:// dx.doi.org/10.1016/i.eururo.2008.01.054

16. Li WM, Shen JT, Li CC, et al. Oncologic outcomes following three different approaches to the distal ureter and bladder cuff in nephroureterectomy for primary upper urinary tract urothelial carcinoma. Eur Urol 2010;57:963-9. http://dx.doi.org/10.1016/i.eururo.2009.12.032

17. Lin, $W C$, Hu FC, Chung SD, et al. The role of lymphovascular invasion in predicting the prognosis of clinically localized upper tract urothelial carcinoma (pT1-3cNOMO). J Urol 2008;180:879-85. http:// dx.doi.org/10.1016/i.juro.2008.05.022

18. Manabe D, Saika T, Ebara S, et al. Comparative study of oncologic outcomes of laparoscopic nephroureterectomy and standard nephroureterectomy for upper urinary tract transitional cell carcinoma. Urology 2007;69:457-61. http://dx.doi.org/10.1016/i.urology.2006.11.005

19. Margulis V, Shariat SF, Matin SF, et al. Outcomes of radical nephroureterectomy: A series from the Upper Tract Urothelial Carcinoma Collaboration. Cancer 2009;115:1224-33. http://dx.doi.org/10.1002/ cncr. 24135

20. Muntener M, Schaeffer EM, Romero FR, et al. Incidence of local recurrence and port site metastasis after laparoscopic radical nephroureterectomy. Urology 2007;70:864-8. http://dx.doi.org/10.1016/i. urology.2007.07.027

21. Roscigno $M$, Cozzarini $C$, Bertini $R$, et al. Prognostic value of lymph node dissection in patients with muscle-invasive transitional cell carcinoma of the upper urinary tract. Eur Urol 2008;53:794-802. http:// dx.doi.org/10.1016/i.eururo.2008.01.008

22. Saito K, Kawakami S, Fujii Y, et al. Lymphovascular invasion is independently associated with poor prognosis in patients with localized upper urinary tract urothelial carcinoma treated surgically. J Urol 2007;178:2291-6. http://dx.doi.org/10.1016/i.juro.2007.08.019

23. Schatteman $P$, Chatzopoulos $C$, Assenmacher $C$, et al. Laparoscopic nephroureterectomy for upper urinary tract transitional cell carcinoma: results of a Belgian retrospective multicentre survey. Eur Urol 2007;51:1633-8. http://dx.doi.org/10.1016/i.eururo.2006.09.016

24. Shimomura $\mathrm{T}$, Ohtsuka N, Yamada H, et al. Patterns of failure and influence of potential prognostic factors after surgery in transitional cell carcinoma of the upper urinary tract. Int I Clin Oncol 2009;14:213-8. http://dx.doi.org/10.1007/s10147-008-0837-4

25. Simone G, Papalia R, Guaglianone $S$, et al. Laparoscopic versus open nephroureterectomy: perioperative and oncologic outcomes from a randomised prospective study. Eur Urol 2009;56:520-6. http://dx.doi. org/10.1016/i.eururo.2009.06.013

26. Simone $\mathrm{G}$, Papalia $\mathrm{R}$, Loreto $\mathrm{A}$, et al. Independent prognostic value of tumour diameter and tumour necrosis in upper urinary tract urothelial carcinoma. BJU Int 2009;103:1052-7. http://dx.doi.org/10.1111/ j.1464-410X.2008.08134.x

27. Wu CF, Pang ST, Chen CS, et al. The impact factors on prognosis of patients with pT3 upper urinary tract transitional cell carcinoma. J Urol 2007;178:446-50. http://dx.doi.org/10.1016/i.juro.2007.03.115

28. Xylinas $E$, Rink $M$, Cha $E K$, et al. Impact of distal ureter management on oncologic outcomes following radical nephroureterectomy for upper tract urothelial carcinoma. Eur Urol 2012 May 4 Epub. http:// dx.doi.org/10.1016/i.eururo.2012.04.052

29. Ouzzane $\mathrm{A}$, Colin $\mathrm{P}, \mathrm{X}$ ylinas $\mathrm{E}$ et al. Ureteral and multifocal tumours have worse prognosis than renal pelvic tumours in urothelial carcinoma of the upper urinary tract treated by nephroureterectomy. Eur Urol 2011;60:1258-65. http://dx.doi.org/10.1016/i.eururo.2011.05.049

30. $\mathrm{Ng}$ CK, Shariat SF, Lucas SM, et al. Does the presence of hydronephrosis on preoperative axial CT imaging predict worse outcomes for patients undergoing nephroureterectomy for upper-tract urothelial carcinoma? Urol Oncol 2011;29:27-32. http://dx.doi.org/10.1016/i.urolonc.2008.10.023 
31. Mason RJ, Kassouf W, Bell DG, et al. The contemporary role of lymph node dissection during nephroureterectomy in the management of upper urinary tract urothelial carcinoma: the Canadian experience. Urology 2012;79:840-5. http://dx.doi.org/10.1016/i.urology.2011.11.058

32. Ku JH, Choi WS, Kwak C, et al. Bladder cancer after nephroureterectomy in patients with urothelial carcinoma of the upper urinary tract. Urol Oncol 2011;29:383-7. http://dx.doi.org/10.1016/j.urolonc.2009.04.007

33. Kobayashi Y, Saika T, Manabe D, et al. Prognostic factors influencing survival after nephroureterectomy for transitional cell carcinoma of the upper urinary tract. Acta Med Okayama 2011;65:143-9.

34. Kim KH, You D, Jeong IG. Muscle-invasive bladder cancer developing after nephroureterectomy for upper urinary tract urothelial carcinoma. Urol Oncol 2012 May 14 Epub. http://dx.doi.org/10.1016/j.urolonc.2012.04.014

35. Godfrey MS, Badalato GM, Hruby GW, et al. Prognostic indicators for upper tract urothelial carcinomo after radical nephroureterectomy: the impact of lymphovascular invasion. BJU Int 2012;1 10:798-803 http://dx.doi.org/10.1111/i.1464-410X.2011.10893.x

36. Burger $M$, Shariat $S F$, Fritsche $H M$, et al. No overt influence of lymphadanectomy on cancer-specific survival in organ-confined versus locally advanced upper urinary tract urothelial carcinoma undergoing radical nephroureterectomy: a retrospective international, multi-institutional study. World J Urol 2011:29:465-72. http://dx.doi.org/10.1007/s00345-011-0705-0

37. Cutress ML, Stewart GD, Wells-Cole $S$, et al. Long-term endoscopic management of upper tract urothelia carcinoma: 20 year single-centre experience. BJU Int 2012;110:1608-17. http://dx.doi.org/10.1111/ j.1464-410X.2012.11169.x

38. Raymundo EM, Lipkin ME, Banez LB, et al. The role of endoscopic nephron-sparing surgery in the management of upper tract urothelial carcinoma. J Endourol 2011;25:377-84. http://dx.doi.org/10.1089/ end.2010.0276

39. Cornu JN, Roupret $M$, Carpentier $X$, et al. Oncologic control obtained after exclusive flexible ureteroscopic management of upper urinary tract urothelial carcinoma. World J Urol 2010;28:151-6. http://dx.doi. org/10.1007/s00345-009-0494-x

40. Rastinehad AR, Ost MC, Vanderbrink BA, et al. A 20-year experience with percutaneous resection of upper tract transitional carcinoma: is there an oncologic benefit with adjuvant bacillus Calmette Guerin therapy? Urology 2009;73:27-31. http://dx.doi.org/10.1016/j.urology.2008.06.026

41. Thompson RH, Krambeck AE, Lohse CM, et al. Endoscopic management of upper tract transitional cell carcinoma in patients with normal contralateral kidneys. Urology 2008;71:713-7. http://dx.doi. org/10.1016/i.urology.2007.11.018

42. Lucas $S M$, Svatek RS, Olgin $G$, et al. Conservative management in selected patients with upper tract urothelial carcinoma compares favourably with early radical surgery. BJU Int 2008;102:172-6. http:// dx.doi.org/10.1111/j.1464-410X.2008.07535.x

43. Sowter SJ, llie CP, Effthimiou I, et al. Endourologic management of patients with upper-tract transitional cell carcinoma: long-term follow-up in a single center. J Endourol 2007;21:1005-9. http://dx.doi. org/10.1089/end.2006.9922

44. Roupret $M$, Traxer 0 , Tligui $M$, et al. Upper urinary tract transitional cell carcinoma: recurrence rate after percutaneous endoscopic resection. Eur Urol 2007;51:709-13. http://dx.doi.org/10.1016/i eururo.2006.07.019

45. Krambeck AE, Thompson RH, Lohse $\mathrm{CM}$, et al. Imperative indications for conservative management of upper tract transitional cell carcinoma. J Urol 2007;178:792-6. http://dx.doi.org/10.1016/i. juro.2007.05.056

46. Johnson $G B$, Fraiman $M$, Grasso $M$. Broadening experience with the retrograde endoscopic management of upper urinary tract urothelial malignancies. BJU Int 2005;95(Suppl 2):110-3. http://dx.doi. org/10.1111/i.1464-410X.2005.05210.x

47. Palou J, Piovesan LF, Huquet J, et al. Percutaneous nephroscopic management of upper urinary trac transitional cell carcinoma: recurrence and long-term followup. J Urol 2004;172:66-9. http://dx.doi. org/10.1097/01.ju.0000132128.79974.db

48. Boorjian S, $\mathrm{Ng}$ C, Munver R, et al. Abnormal selective cytology results predict recurrence of upper-trac transitional-cell carcinoma treated with ureteroscopic laser ablation. J Endourol 2004;18:912-6. http:// dx.doi.org/10.1089/end.2004.18.912

49. Matsuoka K, Lida S, Tomiyasu K, et al. Transurethral endoscopic treatment of upper urinary tract tumors using a holmium:YAG laser. Lasers Surg Med 2003;32:336-40. http://dx.doi.org/10.1002//sm.10184

50. Iborra I, Solsona E, Casanova J, et al. Conservative elective treatment of upper urinary tract tumors: a multivariate analysis of prognostic factors for recurrence and progression. J Urol 2003;169:82-5. http:// dx.doi.org/10.1016/S0022-5347(05)64041-4

51. Goel MC, Mahendra V, Roberts JG. Percutaneous management of renal pelvic urothelial tumors: longterm followup. J Urol 2003;169:925-30. http://dx.doi.org/10.1097/01.ju.0000050242.68745.4d
52. Daneshmand S, Quek ML, Huffman JL. Endoscopic management of upper urinary tract transitional cell carcinoma: long-erm experience. Cancer 2003;98:55-60. http://dx.doi.org/10.1002/cncr.11446

53. Deligne $\mathrm{E}$, Colombel $M$, Badet $L$, et al. Conservative management of upper urinary tract tumors. Eur Urol 2002;42:43-8. http://dx.doi.org/10.1016/S0302-2838(02)00220-8

54. Jabbour ME, Smith AD. Primary percutaneous approach to upper urinary tract transitional cell carcinoma. Urol Clin North Am 2000;27:739-50. http://dx.doi.org/10.1016/S0094-0143(05)70122-1

55. Chen $\mathrm{GL}$, Bagley DH. Ureteroscopic management of upper tract transitional cell carcinoma in patients with normal contralateral kidneys. J Urol 2000;164:1173-6. http://dx.doi.org/10.1016/S0022$5347(05) 67135-2$

56. Keeley FX Jr, Bibbo M, Bagley DH. Ureteroscopic treatment and surveillance of upper urinary tract transitional cell carcinoma. J Urol 1997;157:1560-5. http://dx.doi.org/10.1016/S0022-5347(01)64793-1

57. Martinez-Pineiro JA, Garcia Matres MJ, Martinez-Pineiro L. Endourological treatments of upper tract urothelial carcinomas: analysis of a series of 59 tumors. J Urol 1996;156:377-85. http://dx.doi. org/10.1016/50022-5347(01)65854-3

58. Elliott DS, Blute ML, Patterson DE, et al. Long-term follow-up of endoscopically treated upper urinary tract transitional cell carcinoma. Urology 1996;47:819-25. http://dx.doi.org/10.1016/S00904295(96)00043-X

59. Jarrett TW, Sweetser PM, Weiss GH, et al. Percutaneous management of transitional cell carcinoma of the renal collecting system: 9-year experience. J Urol 1995;154:1629-35. http://dx.doi.org/10.1016/ S0022-5347(01)66732-6

60. Gadzinski AJ, Roberts WW, Faerber GJ, et al. Long-term outcomes of nephroureterectomy versus endoscopic management for upper tract urothelial carcinoma. J Urol 2010;183:2148-53. http://dx.doi. org/10.1016/i.juro.2010.02.005

61. Pak RW, Moskowitz EJ, Bagley DH. What is the cost of maintaining a kidney in upper-tract transitionalcell carcinoma? An objective analysis of cost and survival. J Endourol 2009;23:341-6. http://dx.doi. org/10.1089/end.2008.0251

62. Patel A, Soonawalla $P$, Shepherd SFet al. Long-term outcome after percutaneous treatment of transitional cell carcinoma of the renal pelvis. J Urol 1996;155:868-74. http://dx.doi.org/10.1016/S0022$5347(01) 66330-4$

63. Olgac $S$, Mazumdar $M$, Dalbagni $G$, et al. Urothelial carcinoma of the renal pelvis: a clinicopathologic study of 130 cases. Am J Surg Pathol 2004;28:1545-52. http://dx.doi.org/10.1097/00000478200412000-00001

64. Abouassaly R, Alibhai SM, Shah N, et al. Troubling outcomes from population-level analysis of surgery for upper tract urothelial carcinoma. Urology 2010;76:895-901. http://dx.doi.org/10.1016/j.urology.2010.04.020

65. Li WM, Li CC, Ke HL, et al. The prognostic predictors of primary ureteral transitional cell carcinoma after radical nephroureterectomy. J Urol 2009;182:451-8. http://dx.doi.org/10.1016/i.juro.2009.04.026

66. Chromecki TF, Cha EK, Fajkovic $\mathrm{H}$, et al. The impact of tumor multifocality on outcomes in patients treated with radical nephroureterectomy. Eur Urol 2012;51:245-53. http://dx.doi.org/10.1016/i. eururo.2011.09.017

67. Yafi FA, Novara G, Shariat SF, et al. Impact of tumour location versus multifocality in patients with upper tract urothelial carcinoma treated with nephroureterectomy and bladder cuff excision: a homogeneous series without perioperative chemotherapy. BJU Int 2012;110:E7-13. http://dx.doi.org/10.1111/i.1464410X.2011.10792.x

68. Williams AK, Kassouf W, Chin J, et al. Multifocality rather than tumor location is a prognostic factor in upper tract urothelial carcinoma. Urol Oncol 2013: pii:S1078-1439(11)00464-9. http://dx.doi. org/10.1016/i.urolonc.2011.12.004

69. $O^{\prime}$ Brien $\mathrm{T}$, Ra E, Singh R et al. Prevention of bladder tumours after nephroureterectomy for primary upper urinary tract urothelial carcinoma: a prospective, multicentre, randomised clinical trial of a single postoperative intravesical dose of mitomycin C (the ODMIT-C Trial). Eur Urol 2011;60:703-10. http:// dx.doi.org/10.1016/i.eururo.2011.05.064

70. Cutress ML, Stewart GD, Zakikhani P, et al. Ureteroscopic and percutaneous management of upper tract urothelial carcinoma (UTUC): systematic review. BJU Int 2012;110:614-28. http://dx.doi. org/10.1111/j.1464-410X.2012.11068.x

71. Chen GL, El-Gabry EA, Bagley DH. Surveillance of upper urinary tract transitional cell carcinoma: the role of ureteroscopy, retrograde pyelography, cytology and urinalysis. J Urol 2000;164:1901-4. http://dx.doi. org/10.1016/S0022-5347(05)66913-3

Correspondence: Dr. Christopher Allard, Division of Urology, McMaster University, Hamilton, ON; christopher.allard@medportal.ca 